\title{
Problems and Ways to Improve the Quality of Medical Research in India
}

\author{
Prabhat Kumar Chaudhari ${ }^{1}$ Kunaal Dhingra² \\ 10rthodontics Division, Centre for Dental Education and Research, \\ All India Institute of Medical Sciences, New Delhi, India \\ 2 Periodontics Division, Centre for Dental Education and Research, \\ All India Institute of Medical Sciences, New Delhi, India
}

Ann Natl Acad Med Sci (India) 2021;57:122-122.

We congratulate the author for pointing out that the main problem of contemporary medical research is its poor quality, leading to no or limited impact in clinical practice. The author also discussed measures to improve the quality of conduction and reporting of medical research. ${ }^{1}$ Here, we discuss the main reasons of poor quality of research in India along with suggestions for improvement.

In India, faculties and scientists in medical institutions (or colleges) and the Indian Council of Medical Research (ICMR) laboratories are the backbone for conduction of medical research through postgraduate thesis, intramural research grant (IMRG), and extramural research grant (EMRG). In medical institutions, faculties are mostly busy in clinical care and teaching, with limited or no time for research. Quality of medical research could be enhanced by providing protected time for research to the faculty members in medical institutions as per the recommendation by Dr. Sneh Bhargava Committee Report. ${ }^{2}$ Dr. Sneh Bhargava Committee Report recommends that faculties of apex medical institutes in India are expected to be allotted and also devote time accordingly for teaching including training, research, service delivery including patient care, and corporate activity. For the faculty in basic science department, the recommended division of time is $45 \%$ of time for teaching including training, $45 \%$ of time for research, and $10 \%$ for corporate activity. For the faculty in paraclinical or clinical departments, the recommended time is $30 \%$ of time for the teaching including training, 30\% time for service delivery for paraclinical and patient care for clinical department, and $10 \%$ of time for corporate activities.

published online May 27, 2021
DOI https://doi.org/

$10.1055 / \mathrm{s}-0041-1729773$ ISSN $0379-038 \mathrm{X}$
Address for correspondence Kunaal Dhingra, MDS, MFDS RCPS (Glasg), MFDS RCS (Eng), Periodontics Division, Centre for Dental Education and Research, All India Institute of Medical Sciences, New Delhi 110029, India (e-mail: kunaaldhingra@yahoo.co.in).

The main reason of the increasing quantity of medical research without quality is that, in the current scenario, academic credentials for promotion in new cadre (or new pay scale) are same for both low quality and high quality. There is no added incentive for conducting high-quality research, bringing EMRG, and reporting the research in high-impact journals.

To boost translational research in Indian Institute of Technologies (IITs), faculties are encouraged to initiate start-up companies. ${ }^{3}$ Similarly, medical faculties should be encouraged to establish start-up business models to advance medical research.

In summary, we recommend protected time for research activities for faculty in medical institutions, along with the incentive-based system, to boost the high-quality medical research.

\section{Conflict of Interest \\ None declared.}

\section{References}

1 Indrayan A. Improving the quality of medical research. Ann Natl Acad Med Sci 2020;56(01):6-8

2 Sneh Bhargava Committee Report. Available at: https:// www.aiims.edu/aiims/committee/Sneh\%20Barghava\%20 Commitee\%20\%20Report.PDF. Accessed December 11, 2020

3 Now, IIT-Delhi to fund start-ups owned by its faculty. The Indian EXPRESS. September 20, 2019. Available at: https:// indianexpress.com/article/education/iit-delhi-launches-firescheme-to-encourage-start-ups-by-its-faculty-6008682/. Accessed December 11, 2020 (c) 2021. National Academy of Medical Sciences (India).

This is an open access article published by Thieme under the terms of the Creative Commons Attribution-NonDerivative-NonCommercial-License, permitting copying and reproduction so long as the original work is given appropriate credit. Contents may not be used for commercial purposes, or adapted, remixed, transformed or built upon. (https://creativecommons.org/licenses/by-nc-nd/4.0/).

Thieme Medical and Scientific Publishers Pvt. Ltd. A-12, 2nd Floor, Sector 2, Noida-201301 UP, India 